DOI: $10.25178 /$ nit.2020.2.13

\title{
Новые архивные данные по истории школьного строительства в Туве начала XX века
}

\author{
Виктория Ч. Монгуш \\ Тувинский государственный университет, Российская Федерация
}

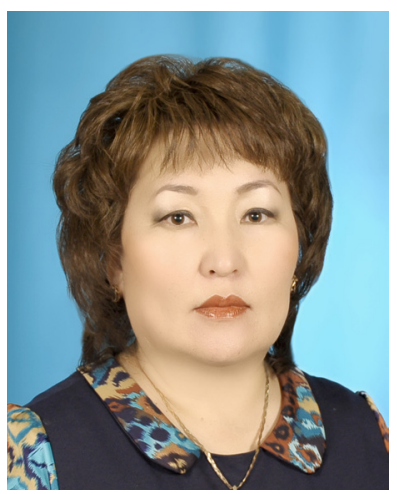

В статье представлен источниковедческий анализ делопроизводственных документов по истории школьного строительства в фонде Управления Заведующего устройством русского населения в Урянхайском крае 1907-1921 г2. Они повествуют о зарождении школьного дела в крае, которое в дальнейшем послужило мощным импульсом развития образования в Тувинской Народной Республике. Документы (914 единиц) хранятся в четырех описях (1-3 и 5) фонда 123 Национального (до 07.04.2020 г. - Государственного) архива Республике Тыва.

Документы относятся к делопроизводственной документации. Сохранность в целом удовлетворительная. Подавляющая часть представлена рукописными материалами, меньшая - напечатана на машинке. Материалы описей неоднородны по объему и количеству единии хранения. Среди них есть доклады, переписки, вырезки из статей, докладные записки, ведомости, дела о кадрах, планы, отчеты, сметы. Особый интерес представляет дело «О назначении учителей в поселки Урянхайского края».

Практически все аспекты деятельности Переселенческого управления по школьному строительству отразились в 29 документах из 3 и 5 описей. Здесь есть переписка, протоколы, доклады, представления, авансовые отчеты и др.

Введение в научный оборот малоизученного комплекса неопубликованных исторических источников позволит существенно расширить источниковое поле исследований по истории образования в республике.

Ключевые слова: Государственный архив Республики Тыва; Национальный архив Республики Тыва; архивные документы; Урянхайский край; русские переселенцы; Переселенческое управление; Тува; история Тувы; история образования

Для цитирования:

Монгуш В. Ч. Новые архивные данные по истории школьного строительства в Туве начала ХХ века // Новые исследования Тувы. 2020, № 2. C. 187-200. DOI: www.doi.org/10.25178/nit.2020.2.13

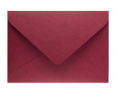

Монгуш Виктория Чарызоловна - кандидат исторических наук, доцент кафедры всеобщей истории, археологии и документоведения исторического факультета Тувинского государственного университета. Адрес: 667000, Россия, г. Кызыл, ул. Ленина, д. 5. Тел. 7 (923) 268-36-08. Эл. адрес: monvik72@mail.ru ORCID ID: 0000-0002-8098-7305

Mongush Victoria Chrysolovna, Candidate of History, Associate Professor, Department of General history, Archaeology and Document Studies, Faculty of History, Tuvan State University. Postal address: 5 Lenin St., Kyzyl, 667000,Russia. Tel.: +7 (923) 268-36-08. E-mail: monvik72@mail.ru 


\title{
New archival data on the history of school construction in Tuva at the beginning of the twentieth century
}

\author{
Victoria Ch. Mongush \\ Tuvan State University, Russian Federation
}

\begin{abstract}
The article is a source study of a number of administrative documents on the history of school construction. The documents are preserved in the collection of the Office of Director of Russian Settlement in the Uriankhai Territory for the years 1907-1921. They illustrate the rise of schools in what came to be the Republic of Tuva - the rise which gave a powerful impetus to the further development of education in the People's Republic of Tuva. 914 archival units of documentation are comprised into four units of opis' (1-3 and 5) within Fond 123 at the National Archives (prior to 07.04.2020 known as the State Archives) of the Republic of Tuva.

All in all, the documents belong to the category of administrative documentation. They are relatively well-preserved, with the largest part handwritten, and a small section typewritten. In their volume and number of archival units, the opis' materials are quite variegated: they include presentations, correspondence, newspaper clippings, memos, registers, employee files, plans, reports and cost sheets. The file "On appointing teachers to work at the settlements of the Uriankhai Territory" is of special interest for researchers.

Almost every aspect of the Resettlement Agency's work concerning school construction can be seen in 29 documents from Opis' 3 and 5, which include meeting proceedings, protocols, presentations, nomination documents, cash advanced reports, etc.

Shedding light on a little-known set of unpublished historical sources will allow us to expand the horizon of studies in the history of education in Tuva.
\end{abstract}

Keywords: State Archives of the Republic of Tuva; National Archives of the Republic of Tuva; archival documents; Uriankhai Territory; Russian settlers, Resettlement Agency; Tuva; History of Tuva; history of education

\section{Введение}

Исследования истории Урянхайского края начала XX вв. является актуальным направлением в современном тувиноведении, так как данный период насыщен важнейшими историческими событиями, оказавшимися судьбоносными для тувинского народа.

За короткий промежуток времени произошли знаковые события, изменившие судьбу Урянхайского края. В связи с установлением протектората России над Урянхайским краем в 1914 г., на территории края начали свое функционирование государственные учреждения, деятельность которых отложилась в фондах Национального архива Республики Тыва (Государственного архива Республики Тыва, ГА PT) ${ }^{1}$. Одним из таких учреждений стало Управление Заведующего устройством русского населения (Переселенческое управление) в Урянхайском крае. Первым заведующим был назначен В. К. Габаев. В феврале 1915 г. по состоянию здоровья он передал дела новому заведующему М. В. Шкунову, который занимал эту должность до апреля 1917 г. Региональное Переселенческое управление для организации своей административной деятельности получало значительные средства, что позволяло проводить обустройство русских переселенцев.

${ }^{1}$ В связи с тем, что переименование архива пришлось на период предпечатной подготовки статьи (7 апреля 2020 г.) далее мы сохраняем в тексте старое название «Государственный архив Республики Тыва» и аббревиатуру «ГА РТ». - ред.

Editors' note: Since the Archives was renamed while editorial work on the article was already under way (April 7, 2020), we have preserved at some places the institution's old name - "State Archives of the Republic of Tuva". 
Целью данной работы является источниковедческий анализ делопроизводственных документов по истории школьного строительства в фонде Управления Заведующего устройством русского населения в Урянхайском крае. Выбор данного аспекта исследования обусловлен тем, что изучение данных архивных документов даст нам наиболее полное представление о зарождении школьного дела в крае, которое в дальнейшем послужило мощным импульсом развития начального образования в Тувинской Народной Республике.

Представляется целесообразным произвести комплексный источниковедческий анализ архивных документов по истории школьного строительства на примере и в рамках деятельности Управления Заведующего устройством русского населения в Урянхайском крае. Специфика деятельности данного учреждения предполагала широкий охват административных вопросов, связанных с водворением переселенцев, начиная от выдачи продовольственных и семейных ссуддо проведения гидротехнических работ в крае. Наряду с сугубо хозяйственными направлениями деятельности, видное место занимало и удовлетворение культурных нужд переселенцев, в том числе и открытие первых школ.

В этой связи указанные архивные документы представляются важным историческим источником, заслуживающим самостоятельного научного исследования.

Архивные документы данного фонда как источниковая база исследований использовалась в работах таких советских ученых, как В. И. Дулов, Ю. Л. Аранчын (Дулов, 1956; Аранчын, 1982). В частности, в фундаментальном труде В. И. Дулова «Социально-экономическая история Тувы (XIX - начало XX века)» во второй главе дана подробная характеристика исторических источников (Дулов, 1956: 32-37). По праву этот труд можно признать почти единственной работой, в которой, наряду с другими архивными материалами, хранящимися в Иркутском архиве и Красноярском краевом музее, проведен подробный анализ фондов Заведующего устройством русского населения в Урянхайском крае в Новосибирском архиве ${ }^{1}$. Он совершенно справедливо полагает, что эти фонды являются одними из ценных собраний материалов по истории Тувы предреволюционного периода. Учитывая специфику работы, автор свое основное внимание сосредоточил на тех архивных документах, в которых в той или иной мере содержались сведения об экономике и социальных отношениях. Тем не менее, для нас весьма ценным является то, что в работе приводится видовая характеристика материалов фонда и данное обстоятельство позволяет в целом составить верное представление о богатейших информационных возможностях архивных документов фонда.

В настоящее время документы фонда вызывают заслуженный интерес и у современных исследователей. В рамках своих научных интересов к ним обращались такие авторы как М. П. Татаринцева, В. Ч. Монгуш, В. М. Дамдынчап, А. А. Стороженко, А. К. Кужугет (Татаринцева, 2017; Дамдынчап, 2019; Стороженко, 2019; Кужугет, 2019). Вне поля зрения исследователей остались источниковедческие аспекты документов по истории школьного строительства.

По рассматриваемому нами периоду отдельных публикаций историков по истории образования начала XX века почти не имеется, за исключением работы Н. М. Моллерова (Моллеров, 2004), где содержатся разрозненные сведения по первым школам русских переселенцев. В «Истории Тувы» 2007 г. имеется упоминание о том, что к началу 1916г. в Белоцарске действовала школа (История Тувы, 2007:61).

Автор данной статьи уже публиковала ряд архивных документов из фонда 123, преимущественно рассмотрено дело 22 из описи 5 «Об открытии школ в поселках Урянхайского края» (ГА РТ, ф. 123, оп. 5, д. 22) (Монгуш, 2017). В ходе дальнейших научных изысканий в Государственном архиве Республики Тыва были выявлены новые архивные документы, которые послужили материалом для настоящей работы. Введение в научный оборот этой информации значительно обогатит для будущих исследователей возможности научных изысканий.

Объектом исследования являются материалы архивных документов Управления Заведующего устройством русского населения в Урянхайском крае, которые хранятся в ГА РТ. Предметом исследования выступили делопроизводственные документы и по истории школьного строительства в Туве начала XX века. Они позволяют проследить сложный путь зарождения школьного дела в Урянхайском крае начала XX века, а также один из аспектов тувинско-русских отношений на стадии их становления. Привлечение архивных материалов позволяет установить неизвестные ранее факты, касающиеся формирования сети первых русских школ на территории Урянхайского края, а также снабжения их учебниками и учебными пособиями и т. д.

${ }^{1}$ В работе автором указано, что теперь (скорее всего, к моменту выхода книги 1956 г. - В. Ч.) фонды находятся в г. Кызыле, в Государственном архиве Тувинской автономной области. 


\section{Характеристика фонда}

Материалы фонда «Управление Заведующего устройством русского населения в Урянхайском крае» в 1949 г. были переданы из Государственного архива Новосибирской области (ГАНО) в архив Тувинской автономной области. При передаче тип фонда определен как «управленческая документация», номер фонда - 47, срок хранения документов - постоянно. В архиве Тувинской автономной области фонду был присвоен № 123 .

В материалах «Путеводителя по фондам Государственного архива Республики Тыва» 2012 г. указано, что хронологические рамки фонда включают период с 1907 по 1921 гг. (Путеводитель ... , 2012: 27-28). Обосновывается это обстоятельство тем, что в фонде имеется также ряд документов Усинского пограничного округа за 1907-1913 гг.

Что касается общего количества документов фонда, то сразу же отметим значительный состав документов фонда, распределенных по описям в следующей последовательности: опись 1 насчитывает 13 дел; опись 2 содержит 226 дел, опись 3 состоит из 646 единиц хранения, опись 5 в своем составе имеет 29 дел.

Простой подсчет дел по описям позволил нам насчитать всего 914 единиц хранения, а не 918, как указано в аннотации фонда, представленной в Путеводителе (там же: 28).

Нам не удалось выяснить, имелась ли изначально при формировании документов фонда опись 4 . На основании вышеизложенного можно установить, что в фонде имеется всего 4 описи.

Если коснуться внешней характеристики документов, то, как правило, большинство документов фонда датированы и заверены подписями. На документах имеются также и отметка о поступлении, которая представлена регистрационным штампом. Здесь же можно указать на наличие бланков документов, по которым нетрудно определить автора документа. Вместе с тем, в делах фонда немало и недатированных документов, в том числе и документов, на которых отсутствуют подписи.

Подробно рассмотрим содержательные характеристики документов фонда. Так как документы образовались в процессе деятельности учреждения, их принято относить к делопроизводственной документации.

В этой связи хотелось бы отметить, что проблемы источниковедческого изучения делопроизводственных документов государственных учреждений России XIX - начала XX века довольно подробно рассматривались в работе Л. Е. Шепелева (Шепелев, 1975). Автор совершенно справедливо полагал, что документы, образовавшиеся в процессе деятельности государственных учреждений, являлись основным источником при изучении большинства проблем истории конца XIX - начала XX века. Видовое разнообразие документов этого периода ставит перед исследователями задачи распознавания и правильного обозначения видов и вариантов документа. Для правильного понимания значения каждого из них и наилучшего его использования, историк должен знать их свойства и отличительные особенности (там же: 249).

Именно делопроизводственные документы в достаточной мере отражают процесс выработки и принятия государственной политики в деле организации школьного дела на начальном этапе. Для этих документов характерно наличие определяемых устоявшейся канцелярской традицией правил внутреннего и внешнего расположения текста, его оформления, устойчивых и повторяющихся элементов (формуляр), а также наличие правил разработки, написания или подписания и прохождения через управленческие инстанции различных видов документов. Делопроизводственным документам присущ особый «канцеляризм», смысловая значимость формул обращения к адресату, наличие множества делопроизводственных помет, которые позволяют судить о времени создания документа, его поступления к адресату, рассмотрения и т. д.

При характеристике документов фонда не следует забывать о том, что начало XX в. является особым периодом в истории государственных учреждений России, а, вместе с тем, и делопроизводства. Делопроизводству придается важнейшее значение, оно рассматривается как особая область государственного управления.

Сохранность документов фонда в целом удовлетворительная несмотря на то, что подавляющая часть документов представлена в рукописном виде: они написаны от руки карандашами и чернилами, цвет которых также различный (красным карандашом в документах выделены резолюции, черным карандашом отмечены дополнения и уточнения). Почерк пишущих лиц зачастую неразборчивый, что осложняет их изучение. 
Меньшая часть напечатана на пишущих машинах, которые в делопроизводстве начали широко применяться в начале XX века. Зачастую краска в таких машинах тоже имела разную цветовую палитру. Такие документы в деле отмечены как листы с текстами на цветной основе.

Среди архивных документов фонда много дел, где листы, физически повреждены, о чем имеется соответствующая отметка сотрудников архива.

Между тем, приходится отмечать, что рукописные документы в настоящее время имеют устойчивую тенденцию к угасанию текста, в связи с чем, хотелось бы пожелать руководству архива перенести эти документы фонда в электронный вид. Это позволило бы шире использовать их информационные возможности для современных исследователей и сохранить их для следующих поколений.

\section{Состав документов описей 1-2}

Материалы фонда первых двух описей неоднородны по объему и количеству единиц хранения.

Опись 1 фонда составлена на трех листах и содержит наименования заголовков дел. Крайними датами описи являются даты с 1913 по 1918 гг. Полистный просмотр и анализ дел описи дает нам основание утверждать, что в данной описи документов, относящихся к школьному строительству, практически не выявлено. В опись включено 13 единиц хранения, представленных разным видовым составом документов. Самым значительным по объему является документ под номером 1 на 453 листах, в котором сконцентрирована разноплановая информация, например, такая как «Доклады и переписка с прокурором Иркутской судебной палаты ...»; «Список населенных мест Урянхайского края с разделением на полицейские участки...»; «Вырезки из статей газеты “Минусинский листок” со статьями об Урянхайском крае» (ГА РТ, ф. 123, оп. 1, д. 1).

Самым небольшим по объему является «Письмо М. В. Шкунова, касающееся обстоятельств работы и отношений между представителями русской власти в Урянхае», представленное всего на 5 листах (ГА РТ, ф. 123, оп. 1, д. 4.).

Если перейти к содержательной характеристике дел описи 1, то выяснится, что из 13 единиц хранения 6 дел посвящены постройке (строительству) Усинской колесной дороги (ГА РТ, ф. 123, оп. 1, дд. 2, 7, 8, 9, 10, 11).

В частности, здесь можно привести названия таких документов, как: «Докладная записка Заведующего устройством русского населения в Урянхае о положении транспорта», «Требовательная ведомость на выдачу содержания техническому персоналу и служащим канцелярии по постройке Усинской колесной дороги», «Служебные записки заведующего дорожно-строительным отделом Енисейского переселенческого района по поводу расходов, произведенных на постройку Усинской колесной дороги», «Счет в израсходовании аванса, отпущенного на постройку Усинской колесной дороги», «Оправдательные документы по постройке и эксплуатации Усинской колесной дороги» и т. д. При этом, среди документов данной группы самыми объемными являются оправдательные документы, представленные 248 листами дела.

Еще одним документом, представляющим интерес для исследователей, является документ из этой описи под наименованием «Списки населенных мест Усинского округа и Урянхайского края с указанием расстояния от г. Минусинска» на 79 листах (ГА РТ, ф. 123, оп. 1, д. 3).

Комплекс личных документов видного политического деятеля в Урянхайском крае начала ХХ в. Алексея Александровича Турчанинова объемом 60 листов представлен в деле 13(ГА РТ, ф. 123, оп. 1, д. 13).

Опись 2 включает в себя 226 дел, датированных 1913-1921 годами. Видовой состав документов описи тоже весьма разнообразен. Наиболее значительными по количеству листов являются такие специфические виды документов, как бухгалтерские документы, представленные, как правило, по годам, в частности, общая кассовая книга, книга междуселенных сумм, главная книга приходов и расходов (ГА РТ, ф. 123, оп. 2, дд. 1, 18, 19, 69, 92, 157, 158).

Самыми многочисленными в данной описи являются дела по личному составу. В частности, 54 дела из 226 единиц хранения содержат информацию о службе должностных лиц регионального Переселенческого управления. Анализ личных дел показал, что, в рассматриваемый период пока еще не сложились единые требования к оформлению личных дел служащих, к составу информации, к формулировке заголовков личных дел. Например, среди дел встречаются такие заголовки как «Личное дело Варлакова» (ГА РТ, ф. 123, оп. 2, д.186), «О службе счетовода по вольному найму Николая Михайловича Мармонт» (ГА РТ, ф. 123, оп. 2, д. 195) и т. д. 
К этой многочисленной группе можно отнести такие дела как, дела об увольнении, выборах и утверждении разных должностных лиц поселковых управлений (ГА РТ, ф. 123, оп. 2, дд. 3, 5, 23, 93); о приеме и передаче должности должностными чинами Переселенческого управления (ГА РТ, ф. 123, оп. 2, дд. 64, 65); дела личного состава частной службы (ГА РТ, ф. 123, оп. 2, дд. 99, 174); дела личного состава государственной службы (ГА РТ, ф. 123, оп. 2, дд. 168, 175). Всего дел данной группы насчитывается 29 единиц.

В достаточном количестве представлен такой вид информационно-справочных документов, как планы, отчеты, сметы, которые содержат значительный количественный материал (ГА РТ, ф. 123, оп. 2, дд. $70,73,141,149,150,151,215)$. Среди них особое место занимают отчеты агронома А. А. Турчанинова (ГА РТ, ф. 123, оп. 2, дд. 149, 150).

Количественный состав поселковых обществ можно проследить по таким документам как, именные списки лиц, проживающих в Урянхайском крае в качестве работников; ходатайства о водворении (поселении) в Урянхайский край; посемейные списки и сведения о состоянии поселковых обществ (ГА РТ, ф. 123, оп. 2, дд. 4, 54, 80, 101, 119).

Часть дел содержит статистическую информацию, сведения о подворном обследовании (ГА РТ, ф. 123, оп. 2, д. 212).

В этой же описи представлены документы, отражающие смену власти, например, об организации комитета рабочих в Белоцарске, о Белоцарском комитете общественной безопасности, о земельном комитете, об Урянхайском краевом совете крестьянских и рабочих депутатов, о свержении Советской власти, о гарнизоне Красной армии и т. д. (ГА РТ, ф. 123. оп. 2, д. д. 213, 214, 218, 221, 222, 223, 224, 225).

Особый интерес в рамках нашего исследования представляет дело 140 «О назначении учителей в поселки Урянхайского края» на 18 листах (ГАРТ, ф. 123. оп. 2,д. 140). Почти все документы дела оформлены на бланках учреждений и должностных лиц с угловым расположением реквизитов. Бланки напечатаны типографским способом, от руки вписаны дата поступления документа и регистрационный номер.

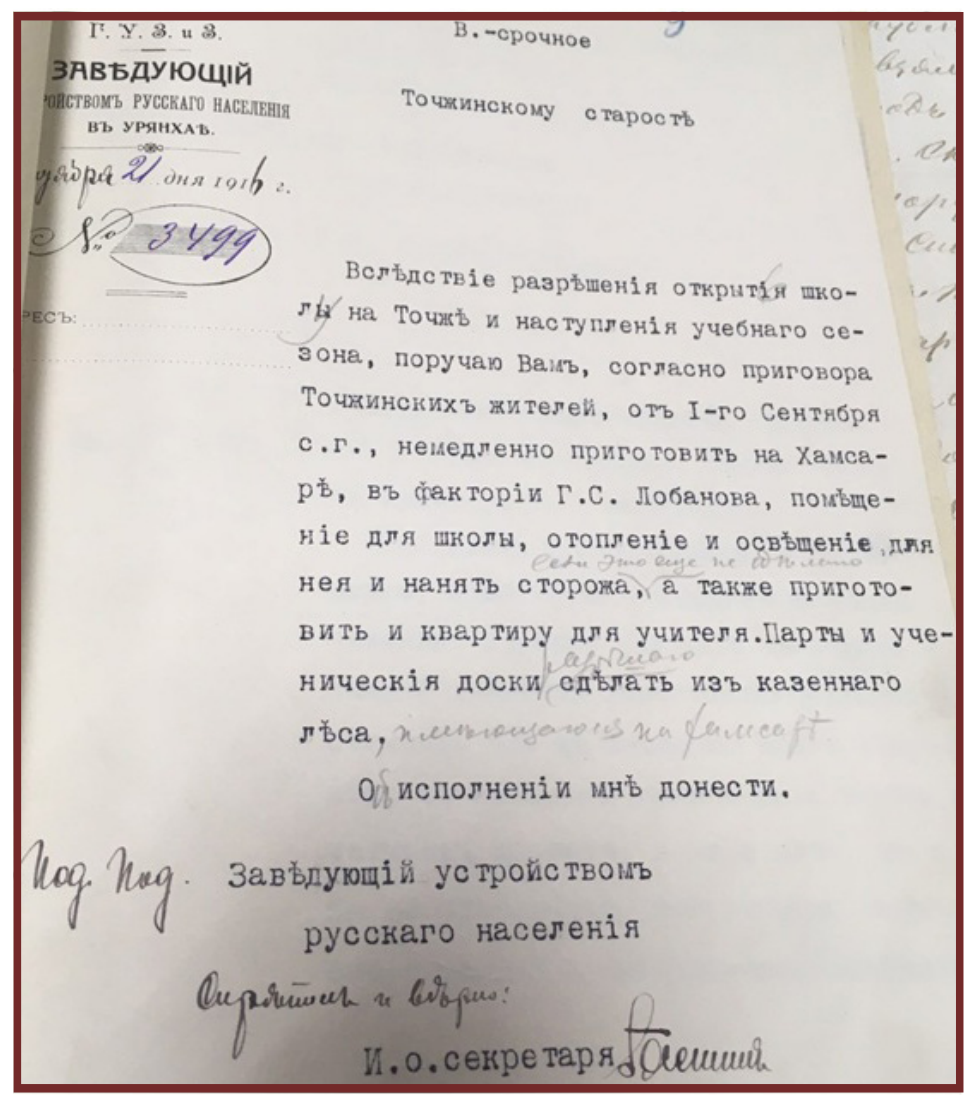

Фото 1. Документ «О назначении учителей в поселки Урянхайского края» (ГА РТ, ф. 123, on. 2, д. 140, л. 7.)

Photo 1. File "On appointing teachers to work at the settlements of the Uriankhai Territory" (SA RT, f. 123, op. 2, d. 140, l. 7)
В состав реквизитов бланка включается наименование учреждения (Министерство Народного Просвещения Российской империи), наименование должности должностных лиц (Инспектор народных училищ 2-го района Енисейской губернии, Комиссар по делам Урянхайского края и Заведующий устройством русского населения в Урянхайском крае). Дата документа также включена в состав реквизитов бланка, как и регистрационный индекс документа, который занимает свое обособленное место. Здесь же совершенно четко можно определить и ссылку на поступивший документ.

Из материалов архивного документа следует, что 22 апреля 1916 г. М. Бахарев уведомляет Заведующего устройством русского населения в Урянхае об отпуске кредитов на открытие пяти школ в Усинско-Урянхайском крае: 1) в поселке Бояровском; 2) в городе Белоцарском; 3) в поселке Атамановском; 4) в поселке Верхне-Никольском; 5) на устье р. Систикема (Сыстыг-Хем. - В. Ч.) для поселков Тоджинского района. В связи с этим, инспектор обращается с просьбой возложить расходы по их содержанию насельские общества в указанных поселках, в частности, об отведении помещений под 
школы и квартиры для учителей, назначение сторожей и другие расходы. Еще одним вопросом, затронутым в документе, является возможность изыскать средства Переселенческому управлению для обеспечения бесплатным проездом учителей от с. Верхне-Усинского к местам назначения.

Здесь же М. Бахарев упомянул о том, что письмо подобного содержания было направлено и Комиссару по делам Урянхайского края.

Не дождавшись ответа, инспектор 9 сентября 1916 г. вновь направляет письмо в Переселенческое управление и Комиссару.

В письме от 24 сентября 1916 г. Пограничный комиссар В. Ю. Григорьев отправляет 5 проездных документов учителям на бесплатный проезд от с. Верхне-Усинского до мест назначения.

Далее в материалах дела последовательно идут распоряжения Заведующего Переселенческого управления старостам поселковых обществ о возложении на сельские общества обязательств по содержанию школ и выделению жилья для учителей.

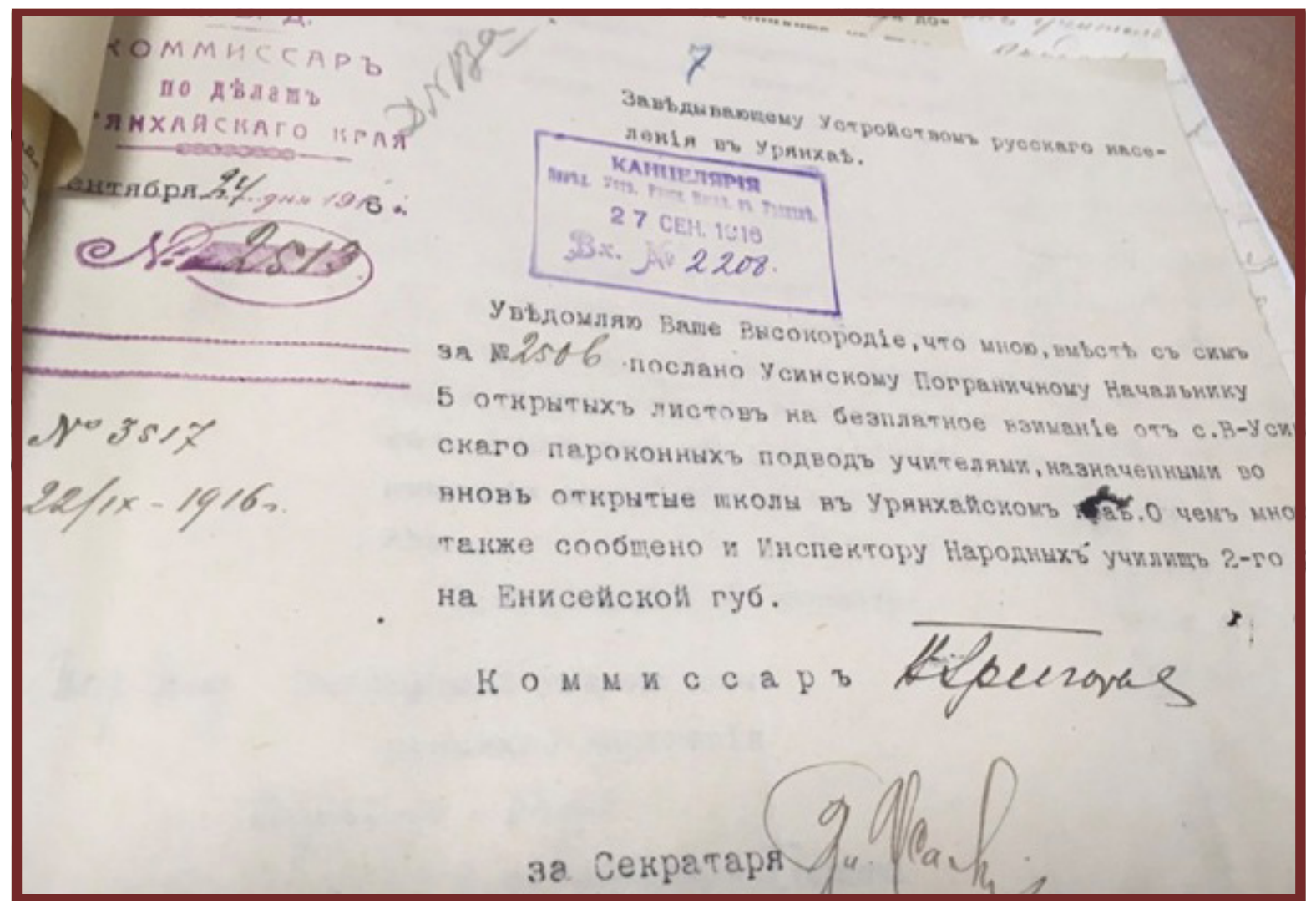

Фото 2. Документ «О назначении учителей в поселки Урянхайского края» (ГА РТ, ф. 123. оп.2, д. 140, л. 9.) Photo 2. File "On appointing teachers to work at the settlements of the Uriankhai Territory" (SA RT, f. 123, op. 2, d. 140, l. 9)

Особую ценность архивному документу придает то обстоятельство, что по его материалам дела можно установить имена первых учителей, назначенных во вновь открытые школы Урянхайского края: А. М. Богатков в Белоцарск, А. Левошин в Тоджу (ГА РТ, ф. 123, оп. 2, д. 140).

Итак, по материалам описи 1 и описи 2 мы определили, что, несмотря на значительное количество дел (всего 239 единиц хранения в двух описях суммарно), информация по школьному строительству нашла отражение лишь в одном документе.

\section{Состав документов описей 3 и 5}

Самой значительной по количеству дел является опись 3, где сосредоточены 646 единиц хранения за 1915-1920 гг.

В первую очередь рассмотрим дело 27 под названием «Выписка из протокола Урянхайского временного краевого съезда, сведения о числе русского населения и о постройке церкви, притчовых домов 
и школ» на 72 листах (ГА РТ, ф. 123, оп. 3, д. 27). Здесь для нас интерес представляет письмо из Главного Переселенческого управления Заведующему устройством русского населения о предоставлении по приложенному образцу сведений о церковно-школьном строительстве с 1907 по 1917 гг.

По поручению регионального переселенческого чиновника техник строительного отдела В. Михайлов представил данные о постройке Переселенческим управлением за период с 1915 по 1916 гг. 4 школ в поселках Урянхайского края: Бояровском, Верхне-Никольском, Чакуль, в местечке Хамсара Тоджи. Наряду с этим, даны сведения о нахождении школ в Белоцарске и поселке Атамановском во временных помещениях.

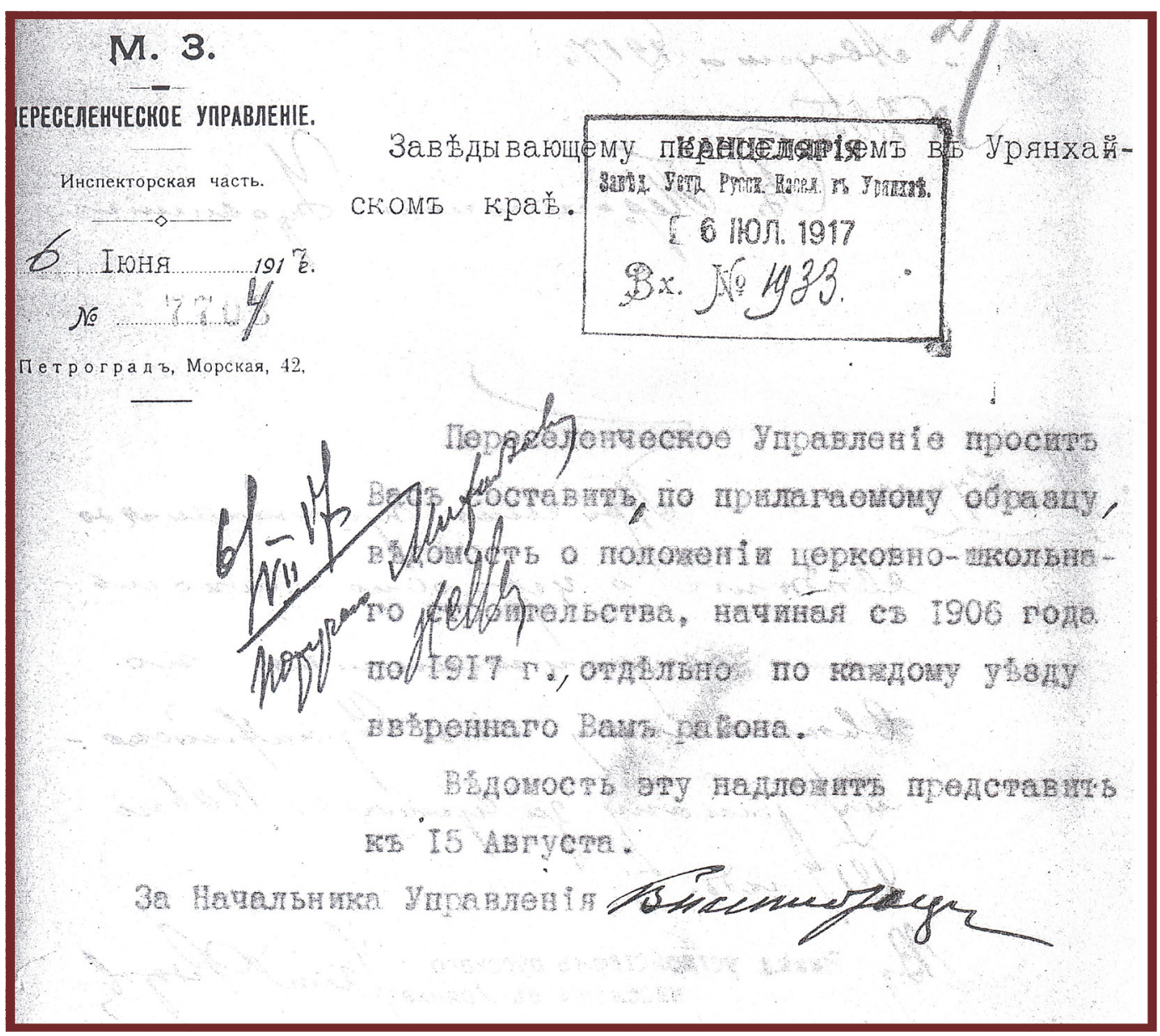

Фото 3. Письмо Главного Переселенческого управления Заведующему устройством русского населения о предоставлении сведений (ГА РT, ф. 123, оn. 3, д. 27, л. 27)

Photo 3. A letter from the Head Migration Department to the Director of Russian Settlement requesting information (SA RT, f. 123, op. 3, d. 27, l. 27)

Также в материалах дела интересным для нас является письмо, где Комиссар по делам Урянхайского края в письме от 4 ноября 1917 г. просит Заведующего устройством русского населения прислать сведения о количестве русского населения в крае.

В ответном письме от 16 ноября сведения были представлены в виде таблицы, где русское население приведено в количестве 8484 человек, из них 4556 мужского и 3928 женского пола - соответственно (ГА РТ, ф.123, оп. 3, д. 27, л. 57).

Можно сказать, что в документах данной описи отложились практически все аспекты деятельности Переселенческого управления по школьному строительству.

Следуя проблематике исследования, условно делопроизводственные документы, хранящиеся в описи, можно разделить на следующие группы: 1) переписка; 2) протоколы; 3) доклады; 4) представления; 5) авансовые отчеты и другая документация. 


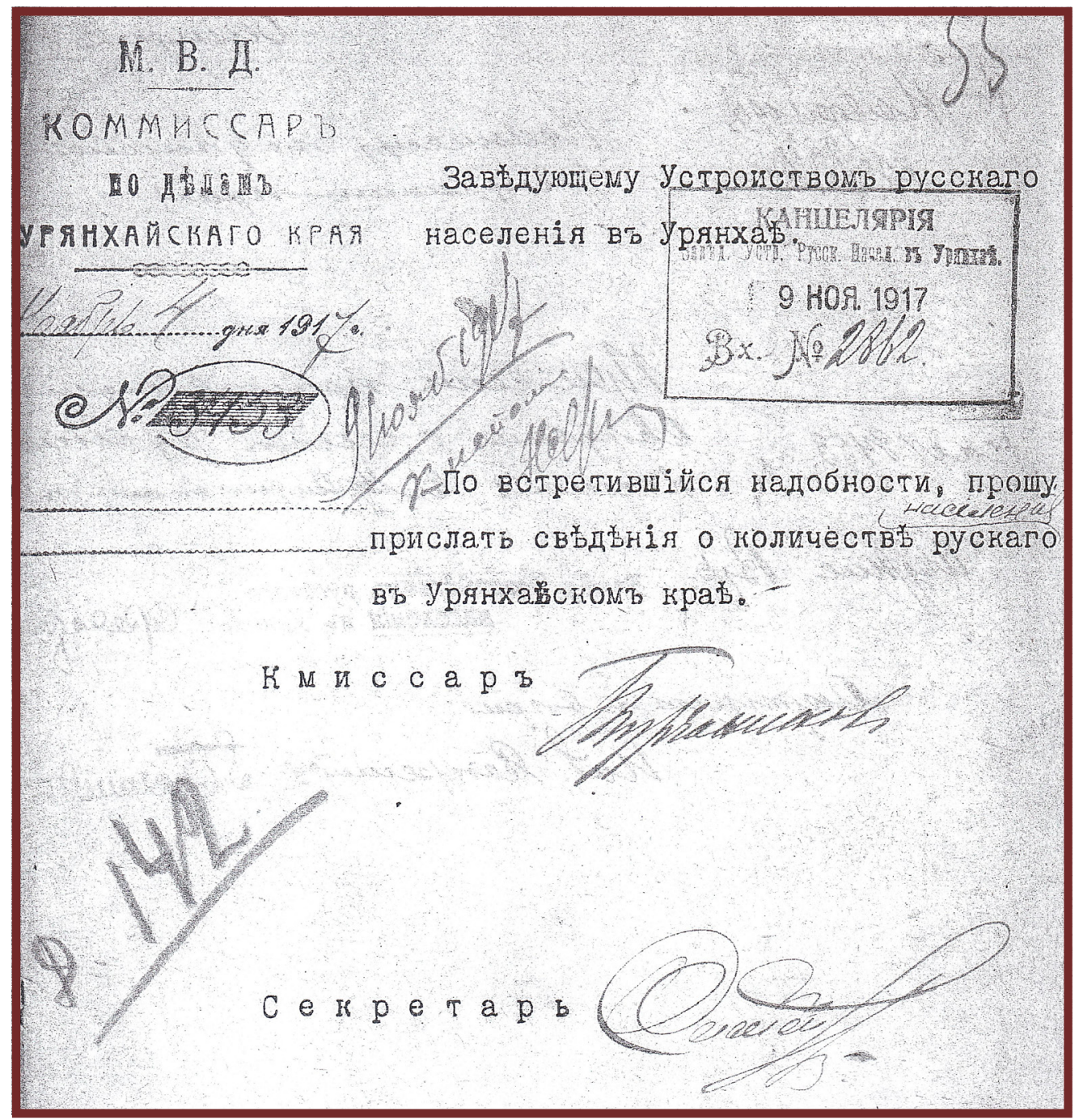

Фото 4. Фото письма Комиссара по делам Урянхайского края Заведующему устройством русского населения о предоставлении сведений (ГА РТ, ф. 123, оп. 3, д. 27, л. 55) Photo 4. A photocopy of the letter from the Commissar for the Affairs of Uriankhai Territory to the Director of Russian Settlement requesting information (SA RT, f. 123, op. 3, d. 27, l. 55)

Раскрыть многогранную деятельность Переселенческого управления по организации школьного строительства можно по документам, обозначенным как «Переписка». Материалы переписки представляют собой наиболее массовый вид управленческой документации, по ним достаточно четко можно проследить систему документальных связей между властью и местными обществами, в данном случае, Переселенческим управлением и поселковыми обществами.

Можно сказать, что служебные письма являются наиболее массовым видом управленческой документации, по этим документам достаточно четко можно проследить взаимоотношения власти и мест, в данном случае, Переселенческого управления и поселковых обществ. Судя по материалам описи, в ней представлено 21 единиц хранения (ГА РТ, ф.123, оп 3, дд. 90, 98, 103, 106, 117, 136, 153, 159, 293, 354, 365, 366, 389, 398, 400, 406, 437, 477, 478, 508, 523).

По архивным материалам можно установить наименования русских поселений, где были заложены основы школьного строительства Урянхайского края. Здесь упоминаются такие поселки как ВерхнеНикольское, Атамановское, Бояровское, Шагонарское, Сосновское, Знаменское, Туран, Уюк. Также упоминаются Тоджа и Белоцарск.

В сентябре 1908 г. была открыта первая школа в Туране (первой из всех культурных учреждений поселения) - самом крупном населенном пункте Тувы до 1914 г. (Моллеров, 2004: 77, 81). Решение о ее строительстве было принято на сходе поселенцев в 1907 г., они сами же и собрали часть средств 
на строительство и оборудование. Значительную сумму пожертвовал А. П. Сафьянов. И недостающие средства выделила казна. Школа была включена в сеть учебных заведений Министерства народного просвещения России (там же: 77-78).

Поскольку школы в поселках Туране и Уюке, также и в Белоцарске, уже функционировали, то и документальные связи Переселенческого управления с этими школами носили иной характер.

В частности, речь шла об устройстве общежития при школе (ГА РТ, ф. 123, оп. 3, д.15), о ремонте школы и дома для квартиры учителя, о постройке бани для учителя, о назначении сторожа в школу, о проведении медицинского осмотра учащихся, о проведении выпускных экзаменов (ГА РТ, ф. 123, оп. 3, д. 103). Судя по архивным материалам, переписка школы в Туране с Переселенческим управлением, с Инспектором народных училищ велась от имени учителя К. Прокопьева.

В других поселках дела со строительством и дальнейшим функционированием первых школ обстояли не так хорошо. Даже, несмотря на положительное решение вопроса о постройке школ частично на средства Переселенческого управления. Требовалось и софинансирование со стороны сельских обществ. Подавляющее большинство первых школ ютилось в неприспособленных помещениях, которые приходилось арендовать у крестьян, в результате чего часто возникали недоразумения между учителями и крестьянами, которые требовали вмешательства чиновников Переселенческого управления.

Несмотря на сложную внутриполитическую обстановку в крае, Переселенческое управление в течение 1917 и всего 1918 г. от старост поселковых обществ настойчиво требовало скорейшей постройки школьных зданий (ГА РТ, ф.123, оп. 3, д. 90, 98, 106, 117).

В свою очередь, сельские общества на сельских сходах принимали «приговоры» - документы, имевшие типовую форму. Например, большой интерес представляют приговоры Знаменского поселка от 1916 г. и 1919 г. Оба документа составлены в соответствии с образцом, отправленным Комиссаром для сведения.

Подробно рассмотрим содержание первого документа - приговор Знаменского поселка Урянхайского края об открытии начального училища Министерства Народного Просвещения. По своей форме приговор имеет форму протокола, с присущими данному виду документа реквизитами. В анализируемом нами приговоре отсутствуют некоторые элементы протокола как документа в современном понимании, например, такие как повестка дня, номер заседания, подробная или краткая запись выступлений и т. д.

Приговор имеет заголовочную часть, в которой указаны следующие сведения: год - «1916», месяц - «май», число - «25», затем указание на название места, где проходит сельский сход - поселок Знаменский. Далее перечислены участники сельского схода (жители поселков Грязнушинский, Даниловский, Медведевский и Знаменский) в количестве 60 человек (при этом оговорено, что это составило более половины домохозяев, имеющих право голоса).

Выражение «имели суждение об открытии двухклассного начального училища ведомства Министерства Народного Просвещения в поселке Знаменском» можно приравнять к элементу «Слушали» протокола. В самих документах это не обозначалось, но по смысловому содержанию и по аналогии со структурой современных протоколов, можно так воспринимать.

Далее идет элемент «Постановили» (опять же условно нами обозначаемый), в котором сначала идет обращение к учебному начальству ходатайствовать об открытии с осени 1916 г. двухклассного смешанного мужского и женского училища на 60 детей. Далее в архивных документах уже присутствует запись «Постановили», в котором сначала идет обращение к учебному начальству ходатайствовать об открытии с осени 1916г. двухклассного смешанного мужского и женского училища на 60 детей.

Затем весьма подробно приводятся обязанности сельского общества по содержанию школы: нанять во временное пользование удобное помещение под училище и квартиру для учителя впредь до постройки собственного здания; нанять сторожа; отдавать детей в учение к 1 сентября, не отрывать их для исполнения домашних, полевых и других работ до окончания учебных занятий 15 мая и т. д. (ГА РТ, ф. 123, оп.3, д.400).

В конце документа даны подписи присутствующих с формулировкой «В чем подписуемся». Примечательно, что в тексте документа подавляющеебольшинство - 41 человек указаны как «неграмотные», а «своеручно подписались» лишь немногие, всего 19 человек.

Судя по дальнейшей переписке, мы обнаружим, что школьное здание так и не было построено. В документах этой же описи, мы обнаружим, что школьное здание так и не было построено (ГА РТ, ф. 123, оп. 3, д. 400). 
Был заготовлен лишь строительный лес, да и тот не был доставлен до места стройки. В связи с этим, приговор от 25 мая 1919 г. постановил ходатайствовать перед Заведующим Переселенческого управления о постройке училища на 150 детей из готового леса, а для дальнейшего продвижения успешной постройки школы избрать строительную комиссию, которая подчиняется Заведующему.

Вопросам снабжения первых школ инвентарем и учебными пособиями посвящен следующий документ (ГА РТ, ф. 123, оп. 3. д. 153). Из переписки следует, что в декабре 1916 г. для Усинско-Урянхайских школ инспектором народных училищ М. Бахаревым были отправлены книги, учебные пособия, школьные принадлежности и печати. Отдаленность края и долгая дорога не способствовали сохранности и целостности отправленного груза.

Например, при получении груза для Туранского и Уюкского училищ (школ) ${ }^{1}$ не хватало по выписке следующего: 2 коробки перьев; 200 штук тетрадей; 32 коробки чернильного порошка; алфавит заглавных букв; 100 книг для ученических библиотек и т. д.

Далее в деле имеются акты со школ о получении учебных пособий. Здесь, наряду с учителями А. Богатковым в Белоцарске, К. Прокопьевым в Туране, А. Левошиным в Тодже, в получении расписываются и другие учителя: из Бояровского училища - учительница Горчакова; из Атамановского учительница О. Масловская; из Уюкского - учительница Прокопьева².

Таким образом, по такой группе документов как «Переписка» можно определить, что становление школьного строительства в русских поселках велось при непосредственном участии сельских обществ, которые изыскивали необходимые средства для развития начального образования.

Также по архивным документам можно определить, что большая доля расходов приходилась и на Переселенческое управление. Это было вполне объяснимо, так как этому учреждению из государственной казны отпускались значительные финансовые средства.

Далее по материалам описи проведен анализ такого вида документов как «Протоколы», представленных такими названиями, как: «Протоколы родителей учеников Белоцарской школы...» (ГА РТ, ф. 123, оп. 3, д. 23), «Выписка из протокола Урянхайского краевого съезда, сведения о числе русского населения и о постройке церкви, притчовых домов и школ» (ГА РТ, ф. 123, оп. 3, д. 27), «Протокол заседания Белоцарского школьного совета и о ежемесячном осмотре учащихся» (ГА РТ, ф. 123, оп. 3, д. 291).

Несмотря на то, что в этой группе документов представлено всего 3 «протокола», в них содержится значительный объем информации. При этом, под термином «протокол» мы подразумеваем делопроизводственный документ, создаваемый для письменного отображения хода коллективного собрания и фиксируемый в строго определенной форме.

Следуяобщепринятымправиламанализапротокола,мыпроведеманализпротоколапервогоУсинскоУрянхайского учительского съезда, состоявшегося с 1 по 5 января 1918 г. в Белоцарске (ГА РТ, ф. 123, оп. 3, д. 365). В отличие от других документов дела, документ имеет внутреннюю композиционную цельность, отпечатан на печатной машинке, сохранность листов дела удовлетворительная.

Примечательно, что к протоколу прилагалась в качестве приложения обширная программа, состоявшая из 32 вопросов. Такое количество вопросов съезда указывало на то значение, которое придавалось его работе. Несмотря на значительное количество вопросов, в тексте протокола они представлены неоднородно.

\footnotetext{
${ }^{1}$ Необходимо отметить минимальную разницу в терминах «школа» и «училище», характерной для сферы начального образования рубежа XIX-XX вв. По отношению к начальным учебным заведениям существовало такое определение как «одноклассное» (со сроком обучения 3-4 года) или «двухклассное» (со сроком обучения 5-6 лет) «сельское училище». Заметим, что на первоначальном этапе в Урянхайском крае функционировали только одноклассные сельские начальные училища, которые давали возможность овладеть элементарными навыками чтения и письма. Лишь в конце рассматриваемого периода произошло преобразование из одноклассных в двухклассные начальные училища в Туране и в Белоцарске, которые давали более качественное образование.

В архивных документах применяемые понятия «училище» и «школа» равнозначны. Исходя из этого, по материалам фонда можно проследить, что на сельские общества возлагалась обязанность по обеспечению школ участком земли, помещением, выделение средств на приобретение учебного оборудования и содержание учителя. В одноклассное училище принимали детей обоего пола с 8-12 лет. Обучение продолжалось три года. Учитель проводил занятия одновременно в младшем, среднем и старшем отделении. Дети изучали Закон Божий, чтение, письмо, элементарную арифметику.

${ }^{2} \mathrm{~B}$ архивных документах не всегда указаны полные данные человека, пропускались инициалы.
} 
Весьма характерным для данного протокола является то обстоятельство, что после краткого изложения каждого вопроса съезда, в его завершении кратко сформулировано решение.

Разноплановую программу работы съезда можно распределить по тематике. В частности, одними из важнейших вопросов являлись административные вопросы: кому подчиняются школы Урянхая в порядке подчинения; сюда же относились вопросы об организации Краевого комитета по народному образованию; о составе уездных комитетов по народному образованию и исполнительных органов учительского союза; об отделении школы от государства; о внутреннем самоуправлении школ; о родительских комитетах; об инструкторах и т. д.

Самую многочисленную группу вопросов можно обозначить как вопросы обучения и воспитания, которые представляли собой большую часть программы (15 вопросов из 32). Перечислим только некоторые из них: о новом методе преподавания; об экзаменах и балльной системе; о преподавании в школах монгольского языка и т. д. Весьма примечательно и то обстоятельство, что на съезде рассматривался также вопрос об обучении в русских школах урянхайских детей.

Второй по количеству является группа вопросов (10 вопросов из 32), посвященных улучшению материально-технического обеспечения школ; выбора типов школьных зданий, наиболее пригодных к местным условиям; выделения квартир для учителей, о выплате им жалования и т. д.

В заключительной части протокола указаны председатель съезда С. Беспалов, товарищ председателя - Н. Венкель, далее перечислены члены съезда в составе 5 человек, секретари съезда - Богатков и Левченко (указаны без инициалов).

Несомненный интерес представляет поименный список участников съезда. Безупречное с точки зрения делопроизводственной практики оформление протокола указывает на высокую квалификацию его составителей, в данном случае, секретарей съезда, которые, несмотря на краткую запись всего хода заседания, сумели до нас донести основное содержание выступлений участников съезда.

Несмотря на обилие фактической информации, представленной в рассматриваемом документе, на наш взгляд, в нем есть и определенные пробелы. В частности, программа начинается с вопроса «Доклад Урянхайской краевой земской управы по вопросу о народном образовании в крае и доклады учащих с мест». В тексте протокола указано, что доклады прилагаются в качестве приложений. Но нам не удалось обнаружить докладов выступающих, за исключением краткой записи выступлений некоторых учителей (Богаткова из Белоцарского училища, Бузуновой из Атамановской школы и др.).

Мы можем лишь предположить, что приложения могли быть утеряны при передаче документов при смене политической власти. Тем не менее, ценность данного документа от этого ничуть не приуменьшается.

Теперь перейдем к анализу завершающей описи 5, в которой содержится 29 единиц хранения. Именно в эту опись входит ряд документов Управления Усинского пограничного округа за 1907-1913 годы, которые даны в Путеводителе как примечания (Путеводитель ..., 2012: 28).

Разнообразие состава заголовков архивных материалов описи дает нам возможность определить такие направления деятельности Усинского пограничного начальника, как «О наблюдении за поведением проживающего в пос. Знаменском Архипа Яковлевича Попова, подлежащего выселению из Урянхая, в случае проявления им склонности к скандалам, дракам и неуживчивости» (ГА РТ, ф. 123, оп. 5, д. 6), «О выдворении из Урянхайского края разных лиц» (ГА РТ, ф. 123, оп. 5, д. 121), «О гидротехнических работах в Урянхае» (ГА РТ, ф. 123, оп. 5, д. 12), «О выдаче разрешений на рубку леса» (ГА РТ, ф. 123, оп. 5, д. 20), «О привлечении к участию русского населения Урянхайского края к расходам на содержание Усинской волостной тюрьмы» (ГА РТ, ф. 123, оп. 5, д. 15) и т. д. Также нашли отражение в делах описи административное, внутреннее и общественное устройство поселков Бегрединский (ГА РТ, ф. 123, оп. 5, д. 14), Баянкол (ГА РТ, ф. 123, оп. 5, д. 16) и Туран (ГА РТ, ф. 123, оп. 5, д. 19).

Самыми объемными по количеству листов являются два дела, это дело «О постройке храма в пос. Туранском» на 190 листах (ГА РТ, ф. 123, оп. 5, д. 4) и дело «Об опеке над сиротой Андреем Монастыршиным и имуществом, оставшееся в пос. Туране, Урянхайского края после смерти гражданина Минусинского уезда, Коптыревской волости Сергея Монастыршина» насчитывающее 161 лист (ГА РТ, ф. 123, оп. 5, д. 13).

В свете интересующего нас аспекта проанализируем два дела, касающиеся открытия и постройки школ в пос. Туранском на 151 листах (ГА РТ, ф. 123, оп. 5 д. 1) и в поселке Уюкском на 133 листах (ГА РТ, ф. 123, оп. 5. д. 2). Оба дела имеют определенную структуру, изложенную во внутренней описи в начале каждого дела. Подавляющая часть документов представляет собой переписку. Среди авторов 
и адресатов служебных писем: инспектор народных училищ Второго района Енисейской губернии, Усинский Пограничный начальник, старшие выборные Туранского и Уюкского поселков и как юридические лица Туранское и Уюкские училища. В переписке отражены многочисленные вопросы о постройке школьных зданий, о выделении усадьбы под школу, о заготовке леса под здание квартиры для учителя, об отоплении и освещении школы, об освящении туранцами построек здания для школы, отчеты о ходе расходования денежных средств, отпущенных на школьное строительство и др.

Нас заинтересовало также дело «Об открытии школ в поселках Урянхайского края», представленное на 18 листах (ГА РТ, ф. 123, оп. 5, д. 22). В материалах дела имеется образец формы приговора сельского общества об открытии школ. В начале приговора присутствовала его дата, указание на сельское общество, в котором происходил сход, количество участников схода и крестьян домохозяев, имеющих право голоса. Указывалось на то, что сход происходил в присутствии сельского старосты, далее следовала формулировка «единогласно приговорили». Наличие такой единообразной формы приговора значительно облегчало для сельских обществ Урянхайского края их желание открыть у себя в поселениях школы. Можно сказать, что приговоры являются ценным источником по деятельности крестьянского самоуправления. Они дают живую информацию о применении законодательства о крестьянском самоуправлении на практике.

Заметим, что большая часть архивных материалов описи 5 представлена в копиях. Мы предполагаем, что это объяснялось целесообразностью сохранения содержания документов на случай утраты или повреждения оригиналов. Потому что материалы описи в основном рукописные. В частности, дело «Об открытии и постройке школы в пос. Туранском» сопровождается итоговой записью в конце, что имеются листы физически поврежденные (18 листов из 151 листов). Соответственно, данное обстоятельство породило стремление создать страховые (гарантийные) копии.

В целом, можно заключить, что материалы описи 5 являются хронологически ранними по отношению к другим трем описям рассматриваемого нами фонда. В ходе работы в Государственном архиве Республики Тыва нам так и не удалось выяснить, содержится ли хронологическая ошибка в нумерации описей фонда или опись 4 утеряна по каким-то причинам. В связи с этим, следует провести переработку всех описей фонда Управления Заведующего устройством русского населения в Урянхайском крае, т. е. пересоставить описи в процессе повторной научно-технической обработки архивных документов.

\section{Заключение}

Таким образом, проанализированная в работе совокупность архивных документов представляет собой ценный источник информации по истории школьного строительства в Урянхайском крае начала XX века. Подробный анализ документов фонда Заведующего устройством русского населения в Урянхайском крае позволил осветить следующий круг вопросов: характеристику самого фонда, краткий обзор описей фонда и анализ документов по школьному строительству, отложившихся в описях 3 и 5.

В общей массе документов учреждения особое место занимают архивные материалы, представляющие собой сложную совокупность информации, объединенной единой темой - школьное строительство в Урянхайском крае начала XX века.

Анализ архивных материалов по истории школьного строительства в Урянхайском крае является составной частью единой исследовательской проблемы, связанной с изучением эволюции школьного образования в Туве первой половины XX века. Данный анализ позволяет уточнить, верифицировать и дополнить фактические данные, имеющиеся в исследованной литературе.

Введение в научный оборот малоизученного комплекса неопубликованных исторических источников позволит существенно расширить источниковое поле исследований по истории школьного строительства в Туве начала XX века, детализировать картину становления школьного образования региональным конкретно-историческим материалом.

\section{СПИСОК ЛИТЕРАТУРЫ}

Аранчын, Ю. Л. (1982) Исторический путь тувинского народа к социализму. Новосибирск : Наука. 337 с.

Дамдынчап, В. М. (2019) Русско-урянхайский суд в период протектората [Электронный ресурс] // Новые исследования Тувы. № 1. URL: https://nit.tuva.asia/nit/article/view/834 (дата обращения: 16.02.2020). DOI: https:// www.doi.org/10.25178/nit.2019.1.10 
Дулов, В. И. (1956) Социально-экономическая история Тувы : XIX - начало ХХ в. М. : Изд-во АН СССР. 608 с.

Кужугет, А. К. (2019) Отчеты агронома Урянхайского края Алексея Турчанинова за 1914-1916 гг. как источник знаний о природопользовании населения Тувы в начале XIX века // Биоразнообразие и сохранение генофонда флоры, фауны и народонаселения Центрально-Азиатского региона. № 5. С. 158-161.

Моллеров, Н. М. (2004) Основание и развитие г. Турана в конце XIX - начале XX века (исторический очерк) // Ученые записки ТИГИ. Вып. 20. Кызыл: Тувинское книжное издательство. 420 с. С. 60-84.

Монгуш, В. Ч. (2017) Формирование школьной сети Урянхайского края (Тувы) в начале ХХ в. // Вестник КИГИ PAH. № 5 (33). C. 42-50. DOI: https://www.doi.org/10.22162/2075-7794-2017-33-5-42-50

Путеводитель по фондам Государственного архива Республики Тыва (2012). 2-е изд., перераб. и доп. / составители: А. М. Дугар-Сюрюн, Т. А. Бондаренко, М. Ш. Куулар, Н. И. Сургутская; отв. ред. А. М. Дугар-Сюрюн. Новосибирск : Сибирское книжное издательство. 460 с.

Стороженко, А. А. (2019) Старообрядческие монастыри «енисейского меридиана» в XX веке: истоки, традиции и современное состояние [Электронный ресурс] // Новые исследования Тувы. № 1. URL: https://nit.tuva.asia/nit/ article/view/826 (дата обращения: 16.02.2020.). DOI: https://www.doi.org/10.25178/nit.2019.1.1

Татаринцева, М. П. (2017) Особенности земледелия русских переселенцев в Туву в начале ХХ века [Электронный ресурс]//Новые исследования Тувы. № 1. URL: https://nit.tuva.asia/nit/article/view/702 (дата обращения: 16.02.2020). DOI: https://www.doi.org/10.25178/nit.2017.1.10

Шепелев, Л. Е. (1975) Проблемы источниковедческого изучения делопроизводственных документов государственных учреждений XIX - начала XX в. // Источниковедение отечественной истории: сборник статей / глав. ред. Н. И. Павленко. М. : Наука. 376 с. С. 248-271.

Дата поступления: 21.02.2020 г.

\section{REFERENCES}

Aranchyn, Yu. L. (1982) Istoricheskii put' tuvinskogo naroda $k$ sotsializmu [The historical path of the Tuvan people to socialism]. Novosibirsk, Nauka. 337 p. (In Russ.).

Damdynchap, V. M. (2019) Russko-uriankhaiskii sud v period protektorata [Russian-Uriankhai court at the time of Russian protectorate over Tuva]. The New Research of Tuva, no. 1 [on-line] Available at: https://nit.tuva.asia/nit/article/ view/834 (accessed: 16.02.2020). (In Russ.) DOI: https://www.doi.org/10.25178/nit.2019.1.10

Dulov, V. I. (1956) Sotsial'no-ekonomicheskaia istoriia Tuvy. XIX - nachalo XX v. [The socio-economic history of Tuva. XIX - early XX centuries]. Moscow, Akademia nauk SSSR Publ. 608 p. (In Russ.).

Kuzhuget, A. K. (2019) Otchety agronoma Uriankhaiskogo kraia Alekseia Turchaninova za 1914-1916 gg. kak istochnik znanii o prirodopol'zovanii naseleniia Tuvy v nachale XIX veka [1914-1916 reports of Alexey Turchaninov, an agronomist from the Uriankhai Territory, as a source of knowledge about the nature of the population of Tuva at the beginning of the $19^{\text {th }}$ century]. In: Bioraznoobrazie i sokhranenie genofonda flory, fauny i narodonaseleniia Tsentral'no-Aziatskogo regiona, no. 5, pp. 158-161. (In Russ.).

Mollerov, N. M. (2004) Osnovanie i razvitie g. Turana v kontse XIX -nachale XX veka (istoricheskii ocherk) [Foundation and development of the town of Turan in the late $19^{\text {th }}$ and early $20^{\text {th }}$ century: a historical essay]. In: Uchenye zapiski TIGI. Vol. 20. Kyzyl, Tuvan book publisher. 420 p. Pp. 60-84. (In Russ.).

Mongush, V. Ch. (2017) Formirovanie shkol'noi seti Uriankhaiskogo kraia (Tuvy) v nachale XX v. [The rise of the school network of the Uriankhai Territory (Tuva) in the early twentieth century]. Oriental Studies / Vestnik KIGI RAN, no. 5 (33), pp. 42-50. (In Russ.). DOI: https://www.doi.org/10.22162/2075-7794-2017-33-5-42-50

Putevoditel' po fondam Gosudarstvennogo arkhiva respubliki Tyva [The guide to the collections of the State Archives of the Republic of Tuva] (2012). Ed. by A. M. Dugar-Siuriun, T. A. Bondarenko, M. Sh. Kuular and N. I. Surgutskaia. 2nd ed. Novosibirsk, Sibirskoe knizhnoe izd-vo. 460 p. (In Russ).

Storozhenko, A. A. (2019) Staroobryadcheskie monastyri “eniseiskogo meridiana v XX veke: istoki, traditsii i sovremennoe sostoyanie [Old Belief monasteries of the «Yenisei meridian» in the 20th century: origins, traditions and current state]. The New Research of Tuva, no. 1 [on-line] Available at: https://nit.tuva.asia/nit/article/view/826 (accessed: 16.02.2020). DOI: https://www.doi.org/10.25178/nit.2019.1.1 (In Russ.)

Tatarintseva, M.P. (2017) Osobennosti zemledeliia russkikh pereselentsev v Tuvu v nachale XX veka [Agricultural practices of Russian settlers in early 20th century Tuva]. The New Research of Tuva, no. 1 [on-line] Available at: https://nit.tuva. asia/nit/article/view/702 (accessed: 16.02.2020). DOI: https:/www.doi.org/10.25178/nit.2017.1.10 (In Russ.)

Shepelev, L. E. (1975) Problemy istochnikovedcheskogo izucheniia deloproizvodstvennykh dokumentov gosudarstvennykh uchrezhdenii XIX - nachala XX v. [Problems of source studies of clerical documents of state institutions in the $19^{\text {th }}$ and early $20^{\text {th }}$ century]. In: Istochnikovedenie otechestvennoi istorii [Source Studies of national history] : a collection of articles / ed. by N. I. Pavlenko. Moscow, Nauka. 376 p. Pp. 248-271. (In Russ.). 